\title{
Turkish Language
}

National Cancer Institute

\section{Source}

National Cancer Institute. Turkish Language. NCI Thesaurus. Code C154180.

The most widely spoken of the Turkic languages, spoken as an official language in

Turkey, Northern Cyprus, and Cyprus. 